\title{
Galactagogue- Its Effect on Milk Yield and Composition
}

\author{
Neelesh Sharma ${ }^{1 *}$, Zul I Huma ${ }^{1}$, Sandeep Gupta ${ }^{2}$, Savleen Kour ${ }^{1}$, S.R. Upadhyay ${ }^{1}$ and Nrip Kishore Pankaj ${ }^{3}$ \\ ${ }^{1}$ Division of Veterinary Medicine, F.V.Sc. E A.H., SKUAST-J, R.S. Pura, Jammu, UT of JEK, INDIA \\ ${ }^{2}$ DASND Animal Nutrition Pvt. Ltd., Indore, M.P., INDIA \\ ${ }^{3}$ Division of Veterinary Medicine, F.V.Sc. E A.H., SKUAST-J, R.S. Pura, Jammu, UT of JEK, INDIA \\ *Corresponding author: N Sharma; E-mail:drneelesh_sharma@yahoo.co.in
}

Received: 20 May, 2021

Revised: 29 July, 2021

Accepted: 04 July, 2021

\begin{abstract}
The aim of this study was to evaluate the effect of a galactagogue Milkease ${ }^{\circledR}$, on the yield and composition of milk. Three multiparous crossbred cows in mid-lactation stages were selected for this study. It was given at the rate of $30 \mathrm{~g}$ twice daily and was fed to the animals for a total period of 2 months. Milk sampling for analysis was done in morning and evening hours once every week during the experimental period. At the end of the trial, it was observed that the galactagogue supplementation resulted in an increase of quality (composition) as well as quantity (Milk yield) of milk in all the three animals. Hence, it is concluded that Milkease ${ }^{\circledR}$ is a combination of all those essential nutrients which helps in increasing the milk yield as well as its composition.
\end{abstract}

\section{HIGHLIGHTS}

0 Galactagogues are the substances that aid in initiation and maintenance of adequate milk production.

0 Milkease ${ }^{\circledR}$ is a blend of balanced essential micronutrients for indigenous and high producing lactating dairy cows.

(0 The composition of Milkease ${ }^{\circledR}$ leads to an overall increase in milk yield along with an increase in milk fat, protein and SNF of lactating animals.

Keywords: Galactagogue, Milk yield, Milkease, Fibrolytic enzymes, Calcium propionate

Various factors impact the overall milk production of a dairy animal including physiological, nutritional, managemental and metabolic disturbances that an animal goes through in its lactation period. There is a rapid fall in progesterone and initiation of milk supply (lactogenesis) after the parturition. Thereafter animal peaks the production in early stage of lactation $\left(6-8^{\text {th }}\right.$ week) due to increase in prolactin secretion, and then there is decline in the levels of prolactin which is not required for the maintenance of lactation (Behera et al., 2013). The value of a dairy animal depends on its ability to produce milk efficiently, effectively and economically. Although India stands at number one in milk production, but the milk production from individual animal is not up to their capacity. Milk production per animal is low in developing countries and the demand for milk and its products is increasing many folds (Sukanya et al., 2014). Hence, it has been a common practice adopted by the farmers to feed their animals with galactagogues to achieve optimum milk production. Besides the use of galactagogue various drugs, hormonal preparations, mineral supplements and feed additives have been tried time and over to increase the productivity of the animals (Divya et al., 2015; Patel et al., 2016).

Galactagogues are nothing but the substances that aid in initiation and maintenance of adequate milk production, as most of them work through their interaction with dopamine receptors and lead to increase in the levels of prolactin

How to cite this article: Sharma, N., Huma, Z.I., Gupta, S., Kour, S. Upadhyay, S.R. and Pankaj, N.K. (2021). Galactagogue- Its Effect on Milk Yield and Composition. J. Anim. Res., 11(04): 751-754.

Source of Support: None; Conflict of Interest: None क) क्ष 
which in turn increases the milk production (Tabares et al., 2014). Ever since the studies have been conducted on the vitamins and essential minerals, milk production per cow has increased substantially, and the feeding and management of cows have changed (less pasture, less forage, and more total confinement). Milkease ${ }^{\circledR}$ is a blend of balanced essential micronutrients for indigenous and high producing lactating dairy cows and buffaloes to increase Dry Matter digestibility, milk production and its composition. It acts by achieving BMR at a faster rate, increases the metabolic processes and causes faster conversion of maintenance diet to production diet.

\section{MATERIALS AND METHODS}

\section{Selection of Animal}

The present investigation was undertaken at a local dairy farm. Three crossbred cows were selected for this study. The cows were multiparous and in their mid-lactation stages.

\section{Feeding}

Apart from feeding galactagogues@30 g twice in a day, daily for a total trial period of 2 months all animals were provided with a same basic diet consisting of dry fodder, green fodder and concentrates separately to meet their requirements for production and maintenance (NRC, 2001).

\section{Sampling and analysis}

The milk yield was recorded daily for pre-trial period of 2 weeks, trial period of 8 weeks respectively. Milk sampling for analysis was done in morning and evening hours once every week during the experimental period. Before collection of samples CMT was done in order to monitor the status of udder for mastitis. Thereafter, $\mathrm{pH}$ and milk composition were done for the samples collected in the trial period.

\section{Statistical analysis}

In the present study, mean was taken as a measure of central tendency and standard error as a measure of random error for statistical analysis.

\section{RESULTS AND DISCUSSION}

The effect of galactagogue supplementation on milk yield is presented in Table 1 which shows the mean values of weekly average milk production for a trial period of 6 weeks. Mean $( \pm$ SEM) daily milk yield (pre-trial) was $5 \pm 0.34 \mathrm{~L} /$ day, $10.9 \pm 0.33 \mathrm{~L} /$ day and $3.9 \pm 0.23 \mathrm{~L} /$ day for $\mathrm{C} 1, \mathrm{C} 2$ and $\mathrm{C} 3$ respectively. From pre-trial period to the trial period the average milk yield in Cow 1 increased from $5 \pm 0.34 \mathrm{~L}$ /day to $7.93 \pm 0.26 \mathrm{~L}$ /day while in Cow 2 average milk yield increased from $10.9 \pm 0.33 \mathrm{~L} /$ day to $19.02 \pm 0.57 \mathrm{~L} /$ day and from $3.9 \pm 0.23 \mathrm{~L} /$ day to $6.06 \pm 0.23$ $\mathrm{L} /$ day in Cow 3 group respectively. An improvement in the average milk yield of all the three animals were observed after supplementing with galactagogue throughout the experimental period.

Table 1: Effect of supplementation of galactagogue supplementation on milk yield and composition.

\begin{tabular}{lllll}
\hline Attributes & Trial & Cow 1 & Cow 2 & Cow 3 \\
\hline Milk Yield & Pre-trial Period & $5 \pm 0.34$ & $10.9 \pm 0.33$ & $3.9 \pm 0.23$ \\
(L/day) & Trial Period & $7.93 \pm 0.26$ & $19.02 \pm 0.57$ & $6.06 \pm 0.23$ \\
Fat & Pre-trial Period & $4.73 \pm 1.02$ & $3.87 \pm 0.84$ & $4.93 \pm 0.63$ \\
$(\%)$ & Trial Period & $5.08 \pm 0.64$ & $4.04 \pm 0.63$ & $5.29 \pm 1.15$ \\
Lactose & Pre-trial Period & $3.54 \pm 0.70$ & $3.4 \pm 0.83$ & $3.3 \pm 0.45$ \\
$(\%)$ & Trial Period & $3.78 \pm 0.13$ & $3.6 \pm 0.09$ & $3.6 \pm 0.11$ \\
SNF & Pre-trial Period & $7.02 \pm 0.98$ & $6.99 \pm 1.01$ & $6.93 \pm 0.51$ \\
$(\%)$ & Trial Period & $7.48 \pm 0.43$ & $7.17 \pm 0.15$ & $7.09 \pm 0.18$ \\
Protein & Pre-trial Period & $2.91 \pm 0.09$ & $2.78 \pm 0.74$ & $2.86 \pm 0.63$ \\
$(\%)$ & Trial Period & $3.09 \pm 0.10$ & $2.95 \pm 0.07$ & $2.95 \pm 0.09$ \\
\hline
\end{tabular}

The effect of supplementing diet with galactagogue on milk fat percentage of crossbred cows is presented in Table-1. In $\mathrm{C} 1, \mathrm{C} 2$ and $\mathrm{C} 3$ cows the increase in fat percentage was observed to be from $4.73 \pm 1.02$ to $5.08 \pm 0.64,3.87 \pm 0.84$ to $4.04+0.63$ and $4.93+0.63$ to $5.29+1.15$ respectively during the trial period.

After six weeks of supplementation of galactagogue, mean SNF percentage of $\mathrm{C} 1, \mathrm{C} 2$ and $\mathrm{C} 3$ increased to $7.48+0.43$, $7.17+0.15$ and $7.09+0.18$ percent respectively. So, it can be concluded that supplementation of galactagogue resulted in improvement of the solid not fat percentage.

Similarly, for lactose and protein percentage of milk an increase from $3.54 \pm 0.70$ to $3.78 \pm 0.13,3.4 \pm 0.83$ to $3.6 \pm 0.09$ and $3.3 \pm 0.45$ to $3.6 \pm 0.11$ in $\mathrm{C} 1, \mathrm{C} 2$ and $\mathrm{C} 3$ and $2.91 \pm 0.09$ to $3.09 \pm 0.10,2.78 \pm 0.74$ to $2.95 \pm 0.07$ and 
$2.86 \pm 0.63$ to $2.95 \pm 0.09$ in $\mathrm{C} 1, \mathrm{C} 2$ and $\mathrm{C} 3$ respectively was observed.

Over the years researchers have been involved in the studies on galactagogues, using mostly herbal extracts and quite a few times hormonal involvement, drugs, mineral supplements, feed additives for the optimum milk production. Milkease ${ }^{\circledR}$ helps in achieving BMR at a faster rate, increases the metabolic processes and causes faster conversion of maintenance diet to production diet. Since it is a blend of essential micronutrients, it fulfils the requirement of animal for their better production. Various components used in this product have been documented individually by different researchers which have led to an increase in milk production.

Use of probiotics leads to increase in milk production, fat, protein as well as SNF. This has well been documented by Vibhute et al. (2011); Yasuda et al. (2007); Yasuda and Fukata (2004) and Singh and Kumar (1996) which is well in accordance with our findings. Vibhute et al. (2011) in their study found the effectiveness of probiotics from the first week of supplementation and marked increase was observed from fourth week onwards. The beneficial effects are likely related to an improved ruminal microbiota subject to probiotics treatment (Xu et al., 2017). However, $\mathrm{Xu}$ and his coworkers in their study could not find any significant difference in the milk composition before and after the trial.

In lactating (dairy) ruminants, dietary choline availability remains low, but the output of methylated compounds in milk is high, and methionine and other methyl group sources are likely to be in short supply, particularly at the onset of lactation. Milkease ${ }^{\circledR}$ contains Rumenprotected choline (RPC), protected from rumen microbial degradation, which acts as a methyl donor, hence leaving a larger supply of methionine for milk production. A tendency for higher milk yield due to the alleviation of $\mathrm{NEB}$, decreased risk of fatty liver and ketosis, reproductive problems, and oxidative stress has been observed by researchers in a number of studies.

In various studies it was observed that RPC supplementation led to increase in milk yield and 3.5\% fat-corrected milk yield during the first 30 days of lactation. These effects were probably due to choline which acts as a methyl donor in dairy cow metabolism. Milk choline concentration and total secretion increase on RPC supplementation as is reported by many authors (Pinotti et al., 2005). In another study by Deuchler et al. (1998), they indicated that choline supplemented in a rumen-protected form is absorbed, and that milk choline is sensitive to post-ruminal choline supply and bioavailability in dairy cows.

It is a well-known fact that calcium is essential for milk synthesis. Calcium propionate can be hydrolyzed into $\mathrm{Ca}^{2+}$ and propionic acid, which in solution form are indispensable sources of nutrients for ruminants as these can be greatly absorbed by the rumen and increase the ionized calcium concentration in the blood. Martins et al. (2019) has shown that supplementation of $200 \mathrm{~g} / \mathrm{d}$ calcium propionate, during early lactation, provided a better energetic supply for dairy cows, which also increases the milk yield and protein, lactose, fat, and total solids contents in milk, despite the reduced dry matter intake. Liu et al. (2010) observed that an increase in the supplementation of calcium propionate improves the energy status, as indicated by the higher levels of glucose, lower BHBA and NEFA in blood, and lower urine ketones. In ruminants, an increase in glucose precursors, such as propionate, could optimize nutrient use and improve milk production (Miranda et al., 2017).

Supplementing dairy cow diets with exogenous fibrolytic enzymes (EFE) has the potential to improve plant cell wall digestibility and therefore, the efficiency of feed utilization (Meale et al., 2014) which in turn improves forage fiber digestion and supports increased milk production in cows

Summing it all up and concluding that the composition of Milkease ${ }^{\circledR}$ has led to an overall increase in milk yield along with an increase in milk fat, protein and SNF of lactating animals used in this trial.

\section{CONCLUSION}

Milkease $^{\circledR}$ is a combination of all those essential nutrients which help in achieving BMR at a faster rate, increase the metabolic processes and a faster conversion of maintenance diet to production diet leading to an overall increase in milk yield as well as composition.

\section{ACKNOWLEDGMENTS}

This study was supported by the project (No.: BT/ PR26321/SPD/9/1307/2017) funded by the Department of Biotechnology, Government of India, New Delhi. 


\section{REFERENCES}

Behera, P.C., Tripathy, D.P. and Parrija, S.C. 2013. Shatavari: Potentials for galactagogue in dairy cows. Indian J. Tradit. Knowl., 12(1): 9-17.

Deuchler, K.N., Piperova, L.S. and Erdman, R.A. 1998. Milk choline secretion as an indirect indicator of postruminal choline supply. J. Dairy Sci., 81: 238- 242.

Divya, K.K., Choudhary, P.L., Khare, A., Choudhary, K.K., Saxena, R.R., Shukla, N., Bharati, K.A. and Kumar, A.M.R.E.N.D.R.A. 2015. Effect of feeds supplemented with Asparagus racemosus on milk production of indigenous cows. Mintage J. Pharma. Med. Sci., 1: 1-6.

Liu, Q., Wang, C., Yang, W.Z., Guo, G., Yang, X.M., He, D.C., Dong, K.H. and Huang, Y.X. 2010. Effects of calcium propionate supplementation on lactation performance, energy balance and blood metabolites in early lactation dairy cows. J. Anim. Physiol. N., 94(5): 605-614.

Martins, W.D.C., Cunha, S.H.M., Boscarato, A.G., de Lima, J.S., Junior, J.D.E., Uliana, G.C., Pedrini, M. and Alberton, L.R. 2019. Calcium propionate increased milk parameters in Holstein cows. Acta Sci. Vet., 47(1): 1-7.

Meale, S.J., Beauchemin, K.A., Hristov, A.N., Chaves, A.V. and McAllister, T.A. 2014. Board-invited review: opportunities and challenges in using exogenous enzymes to improve ruminant production. J. Anim. Sci., 92: 427-442.

Miranda, L.A., Lee-Rangel, H.A., Mendoza-Martínez, G.D., Crosby-Galván, M.M., Relling, A.E., Pinos-Rodríguez, J.M., Rubio, R.R. and Hernandez, M.G. 2017. Influence of calcium propionate on in vitro fermentation of sorghum-based diets. Rev. Fac. Cienc. Agrar., 49(1): 185-192.
National Research Council. 2001. Nutrient Requirements of Dairy Cattle. $7^{\text {th }}$ rev. ed. Natl. Acad. Sci., Washington, D.C.

Patel, V.K., Joshi, A., Kalmal, R.P., Parmar, S.C., Damor, S.V. and Chaudhary, K.R. 2016. Shatavari (Asparagus racemosus), Jivanti (Leptadenia reticulata) and Methi (Trigonellafoenumgraecum): the herbal galactagogues for ruminants. J. Livest. Sci., 7: 231-237.

Pinotti, L., Campagnoli, A., Dell'Orto, V. and Baldi, A. 2005. Choline: Is there a need in the lactating dairy cow? Livest. Prod. Sci., 98(1-2): 149-152.

Singh, S. and Kumar, U. 1996. Effect of supplementation of yeast culture (Yea-Sacc1026) on milk yield and its composition of Murrah buffaloes. Indian J. Anim. Sci., 66: 71-72.

Sukanya, T.S., Rudraswamy, M.S. and Bharathkumar, T.P 2014. Performance of Shatavari based herbal galactogogoue - Milkplus supplementation to crossbred cattle of Maland region. Int. J. Sci. Nat., 5(2): 362-363.

Xu, H., Huang, W., Hou, Q., Kwok, L.Y., Sun, Z., Ma, H., Zhao, F., Lee, Y.K. and Zhang, H. 2017. The effects of probiotics administration on the milk production, milk components and fecal bacteria microbiota of dairy cows. Sci. Bull., 62(11): 767-774.

Yasuda, K. and Fukata, T. 2004. Mixed feed containing dextran improves milk production of Holstein Frisian Dairy cows. $J$ Vet. Med. Sci., 66(10): 1287-1288.

Yasuda, K., Hashikawa, S.S., Tomita, Y., Shibala, S. and Tsuneo. 2007. A new synbiotic consisting of Lactobacillus casei subsp. Casei and Dextran improves milk production of Holstein Dairy cows. J. Vet. Med. Sci., 69(2): 205. 